\title{
Antibacterial activity of Momordica dioica Roxb. fruit pericarp and leaves in bacterial species
}

\author{
Monika T. Pingle ${ }^{1}$, Snehal S. Gadekar ${ }^{1}$, Snehal K. Bhavsar ${ }^{2}$, S. J. Surana ${ }^{2}$ \\ 'Department of Pharmacognosy, M.V.P. Samaja's College of Pharmacy, Gangapur, Nashik, Maharashtra, India, ${ }^{2}$ Department of Pharmacognosy, R.C. Patel Institute of \\ Pharmaceutical Education \& Research, Shirpur, Maharashtra, India
}

Correspondence:

Snehal S. Gadekar, Department of Pharmacognosy, R.C. Patel Institute of Pharmaceutical Education \& Research, Near Karwand Naka, Shirpur - 425405 , Maharashtra, India.

Phone: +91-7588617962.

E-mail: snehal90feb@gmail.com

\section{ABSTRACT}

During the present study, the antibacterial activity of Momordica dioica Roxb. (Cucurbitaceae) fruit pericarp and leaves was done. The methanolic extracts of $M$. dioica were evaluated for antibacterial activity by disc diffusion method. The minimum inhibitory concentration was determined by tube dilution method. The diameter of the zone of inhibition against various Gram-positive and Gramnegative bacteria was measured. The concentration of stock solution was prepared as $1000 \mu \mathrm{g} / \mathrm{ml}$. Ampicillin was used as positive control. The results indicate weakly active inhibition on the growth of Gram-positive bacteria like Staphylococcus aureus followed by Bacillus subtilis, among Gram-negative bacteria Shigella followed by Salmonella typhi in fruit pericarp. In leaf, Gram-positive bacteria like B. subtilis followed by S. aureus, among Gram-negative bacteria Shigella followed by S. typhi.

Keywords: Antibacterial activity, Momordica fruit, minimum inhibitory concentration

\section{Introduction}

Momordica dioica Roxb. ex. Willd is a perennial, dioceous climbing creeper belonging to family Cucurbitaceae. In Marathi, it is known as Kartoli ${ }^{[1]}$ Generally found throughout India, Pakistan, Bangladesh, the Himalayas to Ceylon.

Leaves of plant are simple membranous, broadly ovate in outline, variable in length $3.8-10 \mathrm{~cm}$ by $3.2-8 \mathrm{~cm}$, cordate at the base, deeply lobed in 3-5 triangular lobes, punctated, entire but distantly denticulate, petiole 1.3-4.5 cm long channelled above, pubescent, and glandular. ${ }^{[2]}$ Leaves of the plant are antihelminthic and aphrodisiac. It is also used to make balance of tridosha, and alters pitta, used in fever, asthma, bronchitis, bowel affection, jaundice, piles, hepatic damages, mental digestive disorders, and urinary complaints. The juice of the leaves mixed with coconut, pepper, red sandalwood, etc., to form an ointment and applied to the head to relieve pain in the head. Leaf paste is useful externally to skin as

\section{Access this article online}

Website: http://www.jpbs-online.com

E-ISSN: $2321-0125$

DOI: $10.31555 / \mathrm{jpbs} / 2018 / 6 / 2 / 40-42$

How to cite this article: Pingle MT, Gadekar SS, Bhavsar Sk, Surana SJ. Antibacterial activity of Momordica dioica Roxb. fruit pericarp and leaves in bacterial species. J Pharm BioSci 2018;6(2):40-42.

Source of Support: Nil, Conflict of Interest: None declared. well as fruit and powder of fruit is taken orally 2 or 3 times daily for skin disease. ${ }^{[3]}$

The fruit is the fleshy type seen in the cucumber. Most members have bicollateral vascular bundles.

M. dioica as the average nutritional value of edible fruit was found to be moisture $-84.1 \%$, carbohydrate $-7.7 \%$, protein $-3.1 \%$, fat $-3.1 \%$, fiber $-3.0 \%$, and minerals $-1.1 \%$.

It also contained small quantities of essential vitamins such as ascorbic acid, carotene, thiamine, riboflavin, and niacin. ${ }^{[4,5]}$

Fruit is shortly beaked, obtuse with inner red kernel, densely echinate with soft spines, green and yellow at maturity. Fruits are green and generally used as vegetable.

It possesses many medicinal properties. Fruit are diuretic, alexiteric, stomachic, laxative, hepatoprotective, and have antivenum property. It is also used to cure asthma, leprosy, excessive salivation, anti-inflammatory in case of snake bite, elephantiasis. Used in fever, mental disorders, digestive disorders, and heart diseases and to treat discharge from mucous membrane. Fresh fruit juice is prescribed for hypertension. The fruit is suitable for eating when cooked with a small amount of oil for treating diabetes. Tender fruits are rubbed on skin for pimples and acne. ${ }^{[5,6]}$

Ilango et al. ${ }^{[7]}$ found that preliminary phytochemical analysis revealed the presence of secondary metabolites such as steroids, fatty acids in hexane extract (he) and proteins, saponin glycosides and triterpenes 
in ethyl acetate soluble portion of methanolic extract (easpme) and both extracts were found to be effective mostly against Salmonella typhi and Shigella dysenteriae.

Reddy et al. ${ }^{[8]}$ performed phytochemical screening and showed positive test for steroid, triterpenoids in $\mathrm{CHCl}_{3}$ extract, EtAc extract, and EtOH extract.

Bumrela et al. ${ }^{[9]}$ analyzed the methanolic extract, and aqueous extract of fruits of $M$. dioica were analyzed for the presence of total phenolic content. Methanolic extract showed more promising antimicrobial and antioxidant activity as compared to aqueous extract.

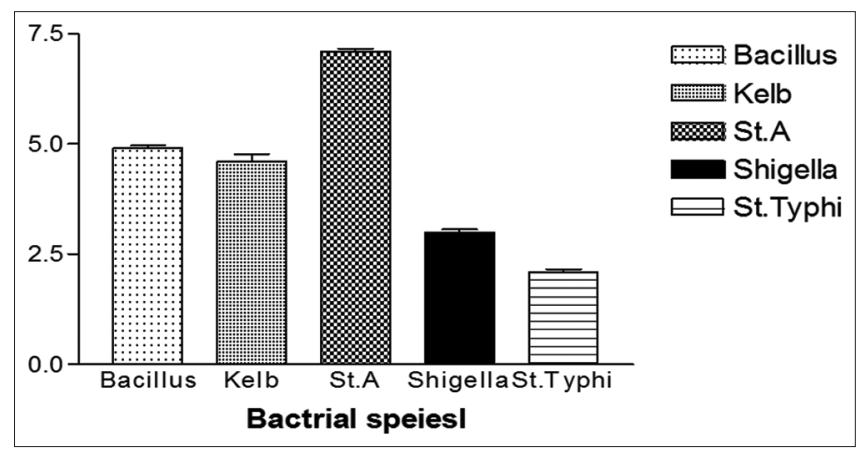

Figure 1: Antibacterial activity: Fruit pericarp

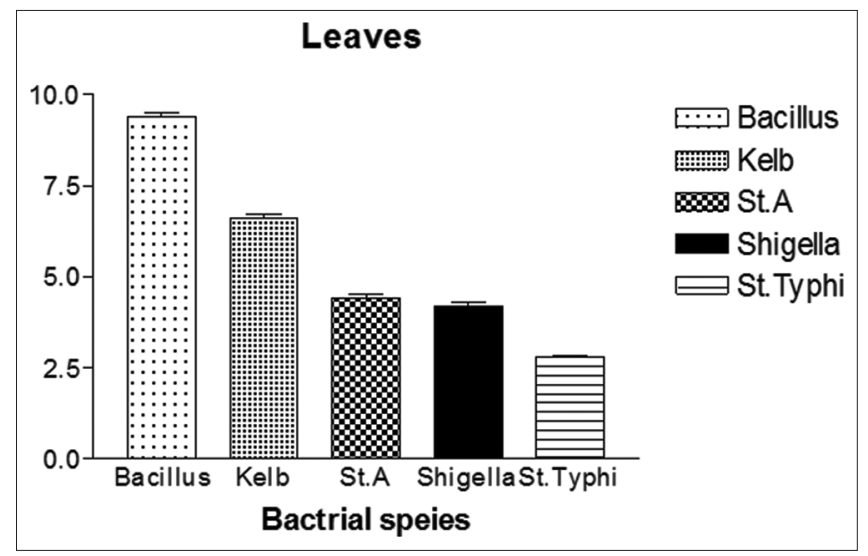

Figure 2: Antibacterial activity of leaves
The present study analyzed the methanolic extract and aqueous extract of fruits of $M$. dioica methanolic extract for antibacterial activity against various bacterial and fungal species.

\section{Material and Methods}

\section{Preparation of extract}

Air-dried fruit pericarp and leaves were processed for size reduction using Cutter Mill (Portable mixer). Crushed material was passed through a $40 \#$ sieve (coarse powder) for uniform particle size, which gave efficient extraction and yield of extract.

\section{Successive extraction method}

The extraction was carried out in Soxhlet extractor till all the constituents were removed. Samples were periodically checked for completion of the extraction procedure by sampling the extract out of Soxhlet extractor and applying it to thin-layer chromatography plate which was subsequently placed in iodine chamber. The absence of colored spot on plate indicated complete extraction. After completion of extraction, the solvent was distilled off, and dried extract was obtained. The marc after exhaustive extraction with petroleum ether was air dried and subjected to exhaustive Soxhlet extraction with methanol. The point of completion of extraction was determined by reaction with iodine vapors. ${ }^{[10-12]}$

\section{In vitro antibacterial assay ${ }^{[8,13,14]}$}

\section{Microbial cultures}

Escherichia coli, S. typhi, Staphylococcus aureus, Bacillus subtilis, Streptococcus, Proteus vulgaris. Antibacterial activity of Fruit pericarp shown in Figure 1, Antibacterial activity of leaves shoen in Figure 2, Antibacterial activity of the fruit pericarp and leaves in methanolic extracts of M. dioica shown in Figure 3.

\section{Antibiotic used}

Streptomycin, ampicillin the agar well diffusion method was used for inoculation of bacteria sample were inoculated uniformly onto the surface of an agar plate. All bacteria samples spread on each plate using spread plate technique then wells were bored in the agar plate,
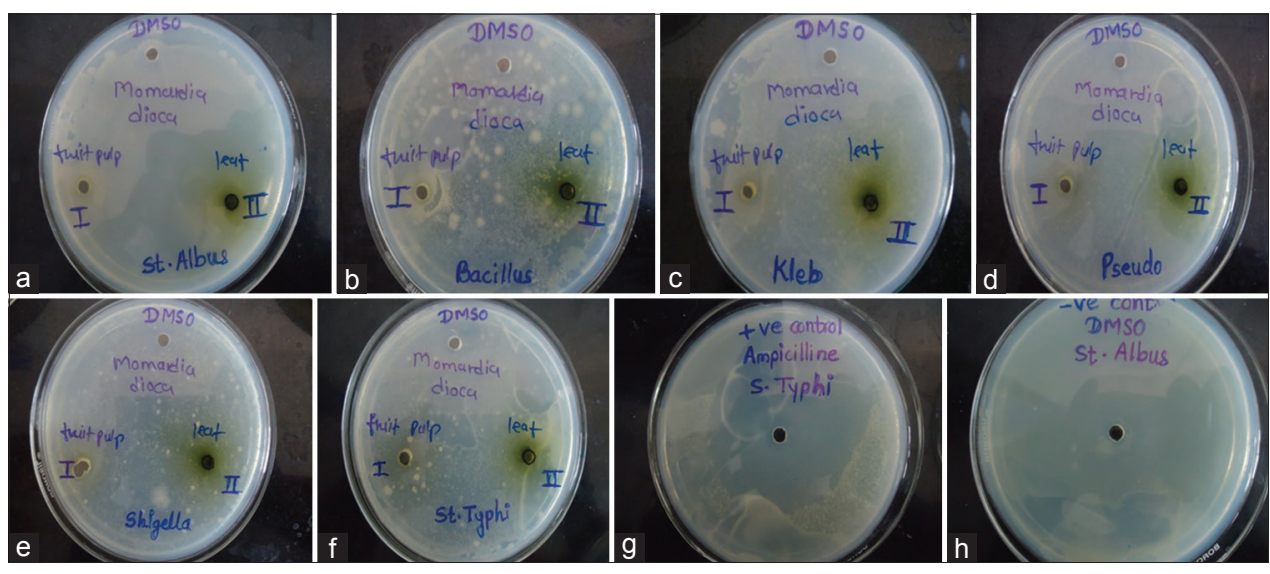

Figure 3: (a-h) Antibacterial activity of the fruit pericarp and leaves methanolic extracts of $M$. dioica 
and in these wells, standard amount of an antibiotic were added and it allowed to diffuse into the adjustment medium. These plates are then incubated for $24 \mathrm{~h}$ at $37^{\circ} \mathrm{C}$.

After $24 \mathrm{~h}$, each plate was examined. The diameter of the zones of complete inhibition was measured, including the diameter of the well using standard zone diameter scale (HIMEDIA). The size of the zones of inhibition is interpreted by referring to standard tables (Johnson et al., 1995). A bacterial lawn appears on the plate, and zones of growth inhibition are measured and recorded in millimeters. The size of zone of inhibition is dependent on the diffusion rate of antibiotic, the degree of sensitivity of the microorganisms, and the growth rate of bacterium.

\section{Minimum inhibitory concentration $(\mathrm{MIC})^{[15,16]}$}

The MIC is the lowest concentrations of an antimicrobial agent that will inhibit the visible growth of the organism. MIC is considered as the "gold standard" for determining MICs is universally accepted to be in doubling dilution step up and down $1 \mathrm{mg} / \mathrm{ml}$ as required. The value is obtained in a highly mechanized fashion, but this procedure only provides interval censored reading. The principles of MIC in MIC dilute on a log 2 scale each antimicrobial agent to provide a range of concentrations, each well containing the antimicrobial agent in plate with a standardized suspension of the microorganisms to be tested. The MIC and the zone diameter of inhibition are inversely correlated. In other words, the more susceptible the microorganism is to the antimicrobial agent, the lower the MIC and the larger the zone of inhibition. Conversely, the more resistant the microorganism, the higher the MIC and the smaller the zone of inhibition.

\section{Result and Discussion}

The antibacterial activity of $M$. dioica Roxb. (Cucurbitaceae) fruit pericarp and leaves was done. The methanolic extracts of $M$. dioica were evaluated for antibacterial activity by disc diffusion method. The MIC was determined by tube dilution method.

The diameter of the zone of inhibition against various Gram-positive and Gram-negative bacteria was measured. The concentration of stock solution was prepared as $1000 \mu \mathrm{g} / \mathrm{ml}$. Ampicillin was used as positive control. The results indicate weakly active inhibition on the growth of Gram-positive bacteria like S. aureus followed by B. subtilis, among Gram-negative bacteria Shigella followed by S. typhi in fruit pericarp. In leaf, Gram-positive bacteria like B. subtilis followed by S. aureus, among Gram-negative bacteria Shigella followed by S. typhi.

Antimicrobial activity of $M$. dioica leaves and fruits was assessed against the above-mentioned bacteria using disc diffusion method.
The antibacterial study shows weakly active inhibition on the growth of Gram-positive bacteria like S. aureus followed by B. subtilis, among Gram-negative bacteria Shigella followed by S. typhi in fruit pericarp. In leaf, Gram-positive bacteria like B. subtilis followed by S. aureus, among Gram-negative bacteria Shigella followed by S. typhi.

\section{Conclusions}

Moderately active antibacterial activity shown by methanolic extract of M.dioica Fruit pericarp and Leaves.

\section{References}

1. Evans WC. Trease and Evans Pharmacognosy. $15^{\text {th }}$ ed. New Delhi: Elsevier; 2005. p. 30.

2. Nadkarni AK. Indian Materia Medica. Vol. I. Mumbai: Popular Prakashan; 2007. p. 807-8.

3. Khare CP. Indian Medicinal Plants, An illustrated Dictionary. New York: Springer; 2008. p. 420.

4. CSIR. The Wealth of India. Vol. 6. New Delhi: Publication and Information Directorate, CSIR; 1962. p. 411.

5. Bawara B, Dixit M, Chauhan NS. Phyto-pharmacology of Momordica dioica Roxb. ex. Willd: A review. Int J Phytomed 2010;2:1-9.

6. Rakh MS, Chaudhari SR. Literature survey of plant Momordica dioica Roxb. Willd: An update. Int J Pharm Res Dev 2010;2 Suppl 4:124-6.

7. Ilango K, Maharajan G, Narasimhan S. Preliminary phytochemical screening and antibacterial activity of fruit pulp of Momordica dioica Roxb. (Cucurbitaceae). Afr J Basic Appl Sci 2012;4:12-5.

8. Reddy BT, Kumar GR, Mohan GK, Mullangi R. Anithyperglycemic activity of Momordica dioica fruits in alloxan-induced diabetic rats. Asian J Pharm Pharm 2006;6:327-9

9. Bumrela S, Samleti A, Parera M, Saxena M. Evaluation of antimicrobial and antioxidant properties of Momordica dioica Roxb. (ex Willd). J Pharm Res 2009;2:1075-8.

10. Pavia DL, Lampman MG, Kriz GS. Introduction to Spectroscopy. $3^{\text {rd }}$ ed. New York: Harcourt College Publication; 2002. p. 68, 72, 77, 152, 153.

11. World Health Organization. Quality Control for Medicinal Plant Material. Vol. 51. New Delhi: World Health Organization; 2004. p. 22-6.

12. Indian Drug Manufacturers Association. Indian Herbal Pharmacopoiea. Revised New Edition. Mumbai: Published by Indian Drug Manufacturers Association; 2002. p. 498-500, 491-2.

13. Mukharjee PK. Quality Control of Herbal Drugs. $1^{\text {st }}$ ed. New Delhi: Business Horizon Publication; 2002. p. 186-96, 388-95.

14. CSIR. The Indian Pharmacopoiea. $6^{\text {th }}$ ed., Vol. I. New Delhi: Controller of Publications, CSIR, Government of India; 2007. p. 89, 189.

15. Vogel GV, editor. Drug Discovery and Evaluation Pharmacological Assay. $2^{\text {nd }}$ ed. Berlin: Springer-Verlag; 2002. p. 696, 702, 716.

16. Kulkarni SK. Hand Book of Experimental Pharmacology. $2^{\text {nd }}$ ed. New Delhi: Vallabh Prakashan; 1999. p. 125-7. 